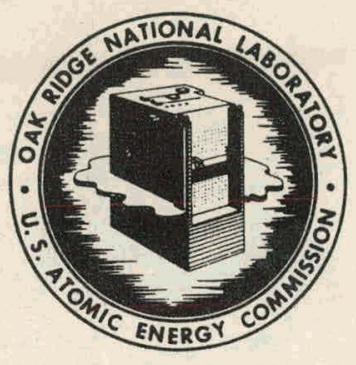

Operoted By UNION CARBIDE NUCLEAR COMPANY

प[C]

POST OFFICE BOX $P$ OAK RIDGE, TENNESSEE

DATE: $\quad$ May 21, 1956

COPY NO. $/ 7$

\title{
SUBJECT: HRR Heat Exchangers
}

TO:

FROM: H. A. MeIain

\section{LEGAL NOTICE}

This report was prepared as an account of Government sponsored work. Neither the United States, nor the Commission, nor any person acting on behalf of the Commission:

A. Makes any warranty or representation, express or implied, with respect to the accuracy, completeness, or usefulness of the information contained in this report, or that the use of any information, apparatus, method, or process disclosed in this report may not infringe privately owned rights; or

B. Assumes any liabilities with respect to the use of, or for damages resulting from the use of any information, apparatus, method, or process disclosed in this report.

As used in the above, "person acting on behalf of the Commission" includes any employee or contractor of the Commission to the extent that such employee or contractor prepares, handles or distributes, or provides access to, any information pursuant to his employment or contract with the Commission.

Photostat Price $\$ 3.30$
Microfilm Price $\$ 2.40$
Available from the
Office of Technical Services
Department of Commerce
Washington 25, D. C.

\section{NOTICE}

This document contains information of a preliminary nature and was prepared primarily for internal use at the Oak Ridge National Laboratory. It is subject to revision or correction and therefore does not represent a final report. 


\section{DISCLAIMER}

This report was prepared as an account of work sponsored by an agency of the United States Government. Neither the United States Government nor any agency Thereof, nor any of their employees, makes any warranty, express or implied, or assumes any legal liability or responsibility for the accuracy, completeness, or usefulness of any information, apparatus, product, or process disclosed, or represents that its use would not infringe privately owned rights. Reference herein to any specific commercial product, process, or service by trade name, trademark, manufacturer, or otherwise does not necessarily constitute or imply its endorsement, recommendation, or favoring by the United States Government or any agency thereof. The views and opinions of authors expressed herein do not necessarily state or reflect those of the United States Government or any agency thereof. 


\section{DISCLAIMER}

Portions of this document may be illegible in electronic image products. Images are produced from the best available original document. 
HRR Heat Exchangers

A study has been made to determine the approximate size of heat exchangers required for heat removal from the homogeneous research reactor. Although limited time prevented the selection of an optimum size heat exchanger, sufficient calculations were made to select one near the optimum size.

Six 83.3 Mw heat exchangers are required to remove $500 \mathrm{Mw}$ of heat from the reactor. Calculations show that the requirements for these heat exchangers is very simflar to the blanket heat exchanger for the TBR. On the basis of the TBR studies ${ }^{l}$, a two drum steam generator is selected with the specifications listed in Table $I$.

\section{Table I}

\section{Steam Generator Specifications}

Reactor Fluids, Forced Clrculation, (Tube Side)

Inlet Temperature, ${ }_{F}$

outlet Temperature, ${ }_{F}$

Flow Rate, Ibs/hr

Pressure, psia

Velocity through tubing; ft/sec

Steam, Natural Recirculation, (Shell side)

Generation Temperature, $\mathrm{O}_{\mathrm{F}}^{\prime}$

Pressure, psia

Generation Rate, Ibs/hr

Heat Load, Btu/hr

Heat Load, Mw
527

437

$2,730,000$

1400

10

417

300

351,600

$284,300,000$

83.3

1 TBR Data Book No. 1 


\section{Steam Generator}

No. of $3 / 8$ in. 18 BWG Tubes

Pitch, in.

Effective Length of Tubing, ft

Heat Transfer Surface, sq. ft

Shell Internal Diameter; in.

Shell Thickness, in.

Tube Sheet Thickness, in.

Reactor Fluid Connections

Number of Risers

Number of Downcomers

Size of Risers and Downcomers

Steam Drum

Internal Diameter, in.

L̈ength, ft.

Wall Thickness, in.

Height above Generator, ft
3280

5/8, Triangular

25.9

8330

$38-1 / 2$

$1-7 / 8$

5

14 inch schedule 100 pipe 12

6

5 inch schedule 40 pipe

Costs per Exchanger

Installed, \$

210,000

Annual, $\$$

39,200

The method of calculation of this heat exchanger gdzelodescribed in the TBR Data Book. I Physical data for the fuel solution was obtained from TBR Memo No. $7^{2}$

The rate of flow of the fuel solution through the heat exchanger may be found by a simple heat balance.

2 A. L. Gaines, TBR Memo No. 7, ORNL CF 54-11-122 (11/12/54) 


$$
\mathrm{W}=\frac{\mathrm{Q}}{\int_{\mathrm{T}_{1}}^{2} \operatorname{cdT}}=\frac{83.3 \times 3.413 \times 10^{6}}{104.3}=2.73 \times 10^{6} \mathrm{lbs} / \mathrm{hr}
$$

The outside surface area of each heat exchanger tube may be found by the following relation ${ }^{1}$

$$
a=w c\left(\frac{D_{0}}{D_{i} h_{1}}+\frac{D_{0}}{D_{w} h_{w}}+\frac{1}{h_{s}}\right) \ln \frac{\phi_{1}}{\phi_{2}}+\frac{w c}{\beta}\left(\frac{1}{\alpha}\right)^{\frac{1}{\beta+1}}\left[\phi_{2}^{-\frac{\beta}{\beta+1}}-\phi_{1}^{-\frac{\beta}{\beta+1}}\right]
$$

where $w$ is the mass rate of flow of fuel solution through the tube. This relation assumes that the inside, walls, and scale coefficients are constant for the length of the tube, but the outside boiling coefficient varies with the length of the tube.

The inside coefficient $h_{i}$. was estimated by the following relation ${ }^{2}$.

$$
\begin{aligned}
h_{1} & =0.023 \frac{k}{D_{i}}\left[\frac{D_{i} G}{\mu}\right]^{0.8}\left[\frac{c \mu}{k}\right]_{\ldots}^{0.3} \\
& =\phi_{i} \quad 0.8 w_{i}^{-1.8}
\end{aligned}
$$

where $w_{i}=$ pounds per hour, and $D_{i}=f t$. The wall coefficlent was assumed to be

$$
\mathrm{h}_{\mathrm{w}}=\frac{\mathrm{k}_{\mathrm{w}}}{\mathrm{x}_{\mathrm{W}}}=\frac{105}{0.049}
$$

and the scale coefficlent $h_{s}$ was assumed to be 2000. The boiling coefficient: $\mathrm{h}_{\mathrm{W}}$ is in the form of

$$
\mathrm{h}_{0}=\alpha(\Delta \mathrm{T})_{0}^{\beta}
$$

where $(\Delta T)_{0}$ is the temperature drop across the boiling film. $\alpha$ is a function of pressure and was evaluated from the information given in the TBR Data Book. ${ }^{1}$ $\beta$ was assumed to be 2.42 .

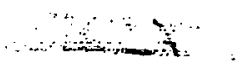


$\phi_{1}$ the heat flux at the hot end of the tube and $\phi_{2}$ the heat flux at the cold end of the tube are then evaluated by the following relation.

$$
\Delta \mathrm{T}_{\mathrm{m}} \alpha^{\frac{1}{\beta+1}} \phi_{\mathrm{m}}^{-\frac{1}{\beta+1}}-\alpha^{\frac{1}{\beta+1}}\left(\frac{D_{0}}{D_{1} h_{i}}+\frac{D_{0}}{D_{w} h_{w}}+\frac{1}{h_{s}}\right) \phi_{m}^{\frac{\beta}{\beta+1}}=1
$$

Calculations using these equations were made for heat exchangers with $3 / 8$ inch 18 gauge tubing and with $1 / 2$ inch 18 gauge tubing. Various velocities were assumed at various steam pressures, and the length of tubing was found by Equation (1) through (5). The number of tubes was found by a simple material balance.

The costs of the various heat exchangers were estimated by the information in TBR Memorandum No. $4^{3}$, and by the letter from A. L. Gaines to C. B. Graham. ${ }^{4}$ From these calculations, the heat exchanger described in Table I appeared to be of a practical size. Heat exchangers with $1 / 2$ inch tubing were too long to be practical and therefore heat exchangers with $3 / 8$ inch tubing were selected.

Wall thicknesses were obtained from the A.S.M.E. Boiler and Pressure Vessel Code ${ }^{5}$ and tube sheet thickness was obtained from the TEMA Code ${ }^{6}$. Sownd $\alpha$ M $M$ Joan

3 M. I. Lundin, TBR Memorandum No. 4, ORNL CTF 54-10-111 (10/25/54).

4 A. L. Gaines, Letter to C. B. Graham (3/25/55).

5 A.S.M.E. Boiler and Pressure Vessel Code, Section VIII, Unfired Pressure Vessels, (1952).

6 TEMA Code, (1952)。 